\title{
Transition from University to the Labour Market: The Impact of Personal Variables in Graduates' Perceptions of Self-Efficacy
}

\author{
Liliana Paulos $1,2, *$, Sandra T. Valadas ${ }^{2}$ and Leandro S. Almeida ${ }^{1}$ \\ 1 Research Centre on Education, Institute of Education, Campus de Gualtar, University of Minho, \\ 4710-057 Braga, Portugal; leandro@ie.uminho.pt \\ 2 Research Centre on Adult Education and Community Intervention, Faculty of Human and Social Sciences, \\ Campus de Gambelas, University of Algarve, 8005-139 Faro, Portugal; svaladas@ualg.pt \\ * Correspondence: lilianasspaulos@gmail.com
}

Citation: Paulos, Liliana, Sandra T Valadas, and Leandro S. Almeida. 2021. Transition from University to the Labour Market: The Impact of Personal Variables in Graduates' Perceptions of Self-Efficacy. Social Sciences 10: 406. https://doi.org/ 10.3390/socsci10110406

Received: 14 September 2021

Accepted: 18 October 2021

Published: 21 October 2021

Publisher's Note: MDPI stays neutral with regard to jurisdictional claims in published maps and institutional affiliations.

Copyright: (c) 2021 by the authors. Licensee MDPI, Basel, Switzerland. This article is an open access article distributed under the terms and conditions of the Creative Commons Attribution (CC BY) license (https:// creativecommons.org/licenses/by/ $4.0 /)$

\begin{abstract}
The transition from university to the labour market is a crucial period for graduates. It is typically characterized by a high degree of uncertainty. Self-efficacy may be a determinant in the process, but the research so far has only considered students or graduates shortly after graduation, strongly compromising its conclusions on the findings. This study aims at exploring the variables which explain the different levels of self-efficacy of graduates in transition to the labour market. A total of 694 graduates who completed their degrees at two Portuguese Higher Education Institutions in the last five years were subjected to a questionnaire. Regression and multivariate analyses based on decision trees (Recursive Partitioning for Classification) showed that (1) older graduates have higher self-efficacy in adapting to work; (2) male graduates have higher self-efficacy in emotional regulation when looking for a job; and (3) graduates with higher grades demonstrated more self-efficacy in job-seeking behaviours. The results also revealed that the graduates' scientific area, the parents' level of education and undergoing internships during higher education are also related to self-efficacy. Overall, the study contributed to a better understanding of the construction process of self-efficacy beliefs and its importance in the job-seeking process and in the adaptation to work.
\end{abstract}

Keywords: self-efficacy; graduates; transition to employment; personal variables

\section{Introduction}

In the last 20 years, the number of students enrolled in Higher Education Institutions (HEI) has doubled worldwide. In Europe, this phenomenon occurred largely after the mid-1980s of the 20th century (Schofer and Meyer 2005). More specifically, in Portugal, there was a substantial increase from the late 1970s to 2020 (from around 81,000 students to almost 400,000 students; Pordata 2021). This trend was accompanied by an exponential growth in the number of graduates, which more than doubled in Portugal between 1994 and 2020 (from 32,622 to more than 83,000; Directorate-General of Education and Science Statistics-DGESS 2020).

The expansion of Higher Education (HE) has increased the number and diversity of institutions, courses and students who attend it (Castro and Almeida 2016). This is reflected in the presence of highly heterogeneous groups of students in terms of previous academic backgrounds, motivations and levels of autonomy (Almeida et al. 2012) and, in the increase of students from disadvantaged socioeconomic groups, first-generation students (MarinhoAraujo and Almeida 2016), mature students (Almeida et al. 2016) and students with disabilities (Pires 2016). In this context of increased diversity, the phenomenon of transition from university to the labour market stems from the confluence of multiple variables (Grosemans and Kyndt 2017). The social class and the parents' level of education, for instance, seem to influence the type of employment that graduates from disadvantaged backgrounds can secure (Holmes 2013). Age can also be a main barrier among mature graduates in accessing graduate employment (Almeida et al. 2016). Additionally, Valadas 
et al. (2018) suggested that gender also influences the transition of graduates to the labour market. In Portugal, statistics indicate that female graduates, when compared to male graduates, take longer to find a job (Directorate-General of Education and Science Statistics-DGESS 2020).

Even the most objective barriers, such as those related to personal variables, may be subject to individual interpretation. The same event or condition may be seen by some graduates as an obstacle, blocking the progress towards professional goals, or as a motivation for improvement in the professional context (Schlossberg 2011). The way the transition to the labour market affects graduates depends, above all, on how graduates perceive it (Schlossberg 2011), and self-efficacy (Bandura 1982, 1997) may be determinant in this process. Self-efficacy is defined as the belief or expectation that, through personal effort, it is possible to successfully perform a certain task (Bandura 1997). In the scope of transitioning to the labour market, graduates are more likely to perform tasks they believe they can perform and less likely to engage in those they feel less capable of doing. Graduates' perceptions of self-efficacy affect the decisions they make, as well as the effort, persistence, and resilience on overcoming potential obstacles, all of which are anticipated to be highly relevant to finding a job or adapting to work (Lent et al. 1999).

There are four sources of self-efficacy (Bandura 1997): mastery experiences (successes and failures), vicarious learning (e.g., observation of role models), verbal persuasion (e.g., social encouragement or discouragement) and physiological and affective states and reactions (e.g., positive and negative emotions associated with task performance). These sources can operate independently or simultaneously. While individuals assess their previous experiences, they may observe the behaviour of peers, receive feedback on their performance or assess their physical and emotional state. Because these processes may interact with each other, they can exert higher or lesser influence on the formation of self-efficacy beliefs (Nunes 2008).

Research carried out in the last decade highlighted the role of self-efficacy in the process of graduates' transition to the labour market. In particular, the study by HernándezFernaud et al. (2011) developed with final year students and recent graduates (up to one year), revealed a positive relationship between self-efficacy in job-seeking and the perception of employability. Vieira (2012), based on the perceptions of final year students, realized that self-efficacy and established goals positively influenced the success of graduates in the transition to employment. Gbadamosi et al. (2015) demonstrated that self-efficacy was significantly associated with career aspiration, confirming the importance of self-efficacy in the role attributed to part-time work among HE students in the UK. Monteiro (2018) found that older students who attended courses in Economics and Engineering had more positive perceptions of their preparation in transitioning to employment when compared to students in Social Sciences and Law. Vieira and Theotonio (2018) highlighted the predictive potential of self-efficacy of recent graduates in regard to their satisfaction with the academicprofessional path and with the actual job. Gamboa et al. (2018) analysed the differences in self-efficacy in the transition to employment between full time students and working students and concluded that this last group is better prepared to successfully cope with the transition process. More recently, Gomes et al. (2019), from a sample of final year HE students, demonstrated that self-efficacy and perceived employability predict job-seeking intentions and behaviours. In addition, self-efficacy in the transition to employment acts as a bridging variable between perceived employability and job-seeking intentions.

Reviewing recent research allowed us, on the one hand, to conclude that studies have been mostly developed with final year students and/or with recent graduates. The fact that these studies took place shortly after graduation (up to one year), or earlier, may strongly compromise conclusions on the topic, especially when considering that the transition to the labour market is a long-term process (Alves and Korhonen 2016; Nicholson 1991). In this respect, it seems relevant to conduct a study that will look at a longer period postgraduation. We realized that most studies have assessed the contribution of self-efficacy in the transition to the labour market, for example, regarding job-seeking intentions (e.g., 
Gomes et al. 2019) or satisfaction with a certain job (e.g., Vieira and Theotonio 2018) but with few studies focused on the contribution of personal traits on self-efficacy in the graduates' transition.

In this study, we aim to (1) assess the self-efficacy of graduates in the transition to the labour market and (2) to explore the predictive effect of multiple personal variables on the perception of self-efficacy in the transition to employment with graduates who completed their highest degree in the last five years.

\section{Materials and Methods}

\subsection{Participants}

A non-probabilistic convenience sample (Schutt 2018) was considered, chosen based on practical criteria (ease of contact, availability, and interest of graduates in participating in the study). Participants volunteered to collaborate in the study through the Alumni offices of two public HEIs with numerous scientific areas, of two distinct regions of Portugal (North and South). Graduates did not receive any kind of incentive to participate in the study.

A sample of 1136 graduates answered an online questionnaire. These participants had completed their highest degree within the last five years, were working at the time (of our questionnaire), were looking for their first job or were unemployed but had previously worked. Those who were exclusively studying or unemployed and not looking for a job or had never worked before, were removed from the sample because they could not provide a real experience of job searching or performing tasks in their current or future job. The final dataset consisted of 694 graduates from the two HEIs. Participants were aged between 21 and 65 years old $(M=30$ years old; $S D=8.27), 73 \%$ were female and approximately $29 \%$ reported at least one parent at a secondary education level (ages 15 to 17), 27\% at a tertiary education level and $40 \%$ at a basic education level (ages 6 to 14). Around 67\% completed their highest degree at the University in the North of Portugal and 33\% at the University in the South in different scientific areas. Overall, Social Sciences was the most prevalent scientific area (58\%), followed by Engineering and Technology (17\%). More than half of the participants completed a master's degree (56\%), followed by a bachelor (35\%) and a PhD degree $(9 \%)$, with a grade point average of 15.3 out of $20(\mathrm{SD}=3.61)$. In terms of their professional status, $88 \%$ of the graduates were working, $9 \%$ were unemployed but had already worked and 3\% were looking for their first job.

\subsection{Measuring Instrument}

TUE Questionnaire-Transition from University to Employment. The questionnaire used in the present study, hereafter referred to as TUE (Transition from University to Employment), was developed and validated elsewhere (article under revision) and resulted from a literature review and the analysis of additional instruments that measure different constructs (e.g., self-efficacy, agency, academic expectations, academic and professional trajectories). TUE includes 119 items with different types of response scales (dichotomous, multiple choice and positioning) divided into six sections of questions. The questionnaire aims at (i) understanding the transition process of graduates from university to the labour market through the characterization of their academic and professional trajectories and at (ii) identifying personal and contextual variables that influence the process of acquiring a job after completing HE. In this study, we used four out of the six sections available in the questionnaire, with a total of 49 items: (1) "sociodemographic characterization" (gender, age, nationality, marital status, residential area, parents' level of education, parents' professional status and occupation); (2) "academic training" (highest academic degree completed, HEI, course, grade point average, undergoing internships, extracurricular and work experience; (3) "current situation vis-à-vis the labour market" (employed, including professional internships, unemployed, looking for a first job, student, inactive); and (4) "transition to the labour market". This last section of the TUE was adapted from the scale of Self-efficacy in the Transition to Employment (SETE) (Vieira and Coimbra 2005), which is composed 
of 3 subscales with 28 items (self-efficacy in adapting to work-SETE-AW-emotional self-regulation in the job-seeking process-SETE-ESR-and self-efficacy in job-seeking behaviours-SETE-JSB).

\subsection{Procedures}

The study was first approved by the Ethics Committee for Research in Social and Human Science of the HEI from the North, which ensures compliance with good research practices. It was also approved by the Data Protection Officer from the HEI in the South.

After the authorization from both Universities, the Alumni Office of these institutions sent the questionnaire to the graduates who had completed their highest degree during the 2015/2016 school year and onwards. Data collection was carried out between March and July of 2020 using the Google Forms platform. This approach allowed us to reduce operative costs and simplified the data collection; considering that data were automatically stored in a database, the approach contributed to eliminating potential errors related to typing (Daikeler et al. 2019).

\subsection{Data Analysis}

The data were analysed with the R software (R Development Core Team 2020) using the packages ggplot2 (to plot results), readxls (to import data), rpart (to model with the Recursive Partitioning for Classification method), rpart.plot (to plot the rpart output) and dismo (to calculate deviance explained of models), with a significance level $<0.05$.

In a first phase, we used descriptive statistics through the calculation of averages and standard deviations, as well as percentages. Some of the variables used were transformed. Notably, from the five nationalities identified in the sample, two groups were created: (1) Portuguese nationality and (2) foreign nationality. In regards to the parents' level of education, only the highest degree of the two was taken into consideration: $1=$ no qualifications; 2 = basic education key stage 1 (ages 6 to 9); 3 = basic education key stage 2 (ages 10 to 11); 4 = basic education key stage 3 (ages 12 to 14 ); $5=$ secondary education (ages 15 to 17); and $6=$ tertiary education. In addition, the courses identified were grouped into major scientific areas: (1) Exact Sciences, (2) Natural Sciences, (3) Engineering and Technology, (4) Health Sciences, (5) Agricultural Sciences, (6) Social Sciences and (7) Humanities.

In a second phase, we determined the average level of confidence per graduate (self-efficacy index) by summing up the responses of each item of the three subscales (SETE-AW, SETE-ESR and SETE-JSB), which is related to the self-efficacy in the transition to employment, and dividing it by the number of items in the respective subscales. This index can vary between 1 and 5 ( 5 being the highest self-efficacy). We determined the global average of self-efficacy per subscale and tested the differences using Mann-Whitney $\mathrm{U}$ paired tests, adjusting the significance level for non-independent analyses with the Bonferroni correction.

Statistical modelling was performed to identify which variables may explain the different levels of self-efficacy in the transition to the labour market. Models were developed considering the average level of self-efficacy of graduates as a dependent variable and 11 independent variables: age, gender, nationality, higher education institution, highest degree completed, scientific area and grade point average of last degree completed, internships, extracurricular activities and work experience and parents' level of education. Prior to developing the models, correlations between the independent variables were tested using the Pearson correlation index since highly correlated pairs of variables (Pearson correlation $>0.5$, or even $>0.7$ ) do not allow for fully estimating their individual effect in the models. In this test, the pair age and marital status was found mildly correlated (Pearson correlation $=-0.55)$, and thus we opted to use the first variable, as considered by additional studies (e.g., Monteiro et al. 2016; Woodfield 2011) and exclude the latter. 
Linear regression analysis and multivariate analysis were used based on decision trees, namely, the Recursive Partitioning for Classification method (RPart; Strobl et al. 2009; Therneau et al. 2013). The latter approach was chosen because it is based on a flexible algorithm with high predictive performance and has been advocated for studies in the field of Education (Gomes and Almeida 2017; Nachev 2017). The data are iteratively divided along the coordinate axes of the independent variables, generating partitions along the decision tree (nodes of branches) that tend to maximize the likelihood of the dependent variable. Decision-making in the RPart algorithm is carried out until the tree runs out of data on the dependent variable, thereby generating terminal branches, also called leaves. To produce simpler and more general models, free from potential overfitting, the complexity of the decision tree was reduced. In this process, a 10-fold cross-validation approach (Strobl et al. 2009) was implemented to identify the optimal parameters of the algorithm amongst different levels of tree complexity (1 to 8 branches; complexity parameter), and minimum number of data allowed to generate a new branch on the tree (from 1 to 200; minsplit parameter; Lopez-Zafra et al. 2019; Nachev 2017). In the cross-validation, the data were divided into two groups, one with $90 \%$ of the data to train the trees and a second group, with $10 \%$ of the data, to test the performance of the generated trees when predicting the dependent variable. This was performed 10 times, never repeating the same data to train/test the model. The final model was chosen as that producing, on average, the smallest deviance in cross validation. Finally, deviance explained was determined as well as the relative importance of each variable to the model.

\section{Results}

In Table 1, some descriptive measures are presented for the three subscales: selfefficacy in adapting to work (SETE-AW), emotional self-regulation in the job-seeking process (SETE-ESR) and self-efficacy in job-seeking behaviours (SETE-JSB).

Table 1. Self-efficacy of graduates per item, in each subscale, considering the average and standard deviation, minimum and maximum and global average of self-efficacy in each subscale.

\begin{tabular}{|c|c|c|c|c|}
\hline \multicolumn{5}{|c|}{ Scale of Self-Efficacy in Transition to Employment (SETE) } \\
\hline Item & Description & Min-Max & Avg & SD \\
\hline \multicolumn{5}{|c|}{ Subscale: Self-efficacy in adapting to work (SETE-AW) $(n=694)$} \\
\hline 17 & Performing my duties well... & $1-5$ & 4.10 & 0.83 \\
\hline 18 & Solving unexpected problems at workplace. & $1-5$ & 3.96 & 0.87 \\
\hline 19 & Believe in my abilities... & $1-5$ & 4.06 & 0.89 \\
\hline 20 & Communicating well with co-workers. & $1-5$ & 4.12 & 0.87 \\
\hline 21 & Adapting to changes that may occur in my duties. & $1-5$ & 3.97 & 0.86 \\
\hline 22 & Working well in a team. & $1-5$ & 4.18 & 0.83 \\
\hline 23 & Fulfilling all the tasks that my job requires. & $1-5$ & 4.13 & 0.82 \\
\hline 24 & Committing myself to fulfilling my duties. & $1-5$ & 4.32 & 0.79 \\
\hline 25 & Demonstrating security in what I do... & $1-5$ & 4.10 & 0.85 \\
\hline 26 & Establishing a good relationship with co-workers. & $1-5$ & 4.25 & 0.84 \\
\hline 27 & Adapting to my needs at my job. & $1-5$ & 4.18 & 0.80 \\
\hline \multirow[t]{2}{*}{28} & Contributing with new ideas at workgroup. & $1-5$ & 4.05 & 0.88 \\
\hline & Global average of self-efficacy & $1-5$ & 4.12 & 0.11 \\
\hline
\end{tabular}


Table 1. Cont.

\begin{tabular}{|c|c|c|c|c|}
\hline \multicolumn{5}{|c|}{ Scale of Self-Efficacy in Transition to Employment (SETE) } \\
\hline Item & Description & Min-Max & Avg & SD \\
\hline \multicolumn{5}{|c|}{ Subscale: Emotional self-regulation in job-seeking process (SETE-ESR) $(n=694)$} \\
\hline 3 & Don't be discouraged after a job refusal. & $1-5$ & 3.28 & 1.10 \\
\hline 4 & Seeking for job opportunities on the Internet. & $1-5$ & 3.68 & 1.11 \\
\hline 5 & Continuing to think that I will get a job after several refusals. & $1-5$ & 3.44 & 1.12 \\
\hline 7 & Don't give up looking for a job even if I have a lot of negative answers. & $1-5$ & 3.54 & 1.08 \\
\hline 8 & Applying for job positions online. & $1-5$ & 3.01 & 1.22 \\
\hline 9 & Dealing with frustration after a job refusal. & $1-5$ & 3.33 & 1.07 \\
\hline 10 & Selecting the most interesting jobs for me. & $1-5$ & 3.65 & 1.02 \\
\hline 12 & Continuing to respond to newspaper ads after many unanswered applications. & $1-5$ & 3.10 & 1.23 \\
\hline 13 & Don't be discouraged by difficulties in getting a job. & $1-5$ & 3.38 & 1.12 \\
\hline 14 & No... having defeatist thoughts after job refusal. & $1-5$ & 3.35 & 1.13 \\
\hline 15 & Being persistent in my job-seeking. & $1-5$ & 3.75 & 1.04 \\
\hline 16 & ... to think that I will find a job after a job refusal. & $1-5$ & 3.59 & 1.08 \\
\hline & Global average of self-efficacy & $1-5$ & 3.42 & 0.24 \\
\hline \multicolumn{5}{|c|}{ Subscale: Self-efficacy in job-seeking behaviors (SETE-JSB) $(n=694)$} \\
\hline 1 & Responding to job offers... & $1-5$ & 3.29 & 1.19 \\
\hline 2 & Applying to employment office... & $1-5$ & 2.98 & 1.28 \\
\hline 6 & Applying to recruitment agencies. & $1-5$ & 3.03 & 1.22 \\
\hline 11 & Getting guidance from employment support services at the university. & $1-5$ & 2.70 & 1.22 \\
\hline & Global average of self-efficacy & $1-5$ & 3.00 & 0.24 \\
\hline
\end{tabular}

The average self-efficacy index showed significant differences between all subscales (Table $1 ; p$-value SETE-AW vs. SETE-ESR $=2.2 \times 10^{-16} ; p$-value SETE-AW vs. SETE-JSB = $2.2 \times 10^{-16} ; p$-value SETE-ESR vs. SETE-JSB $\left.=5.9 \times 10^{-16}\right)$.

The average self-efficacy index in the SETE-AW subscale was $4.12(\mathrm{SD}=0.11 ; \mathrm{min}=1$ and $\max =5$ ), the highest value among the three subscales. Overall, this means that participants were very confident in performing specific tasks at work (e.g., "committing myself to fulfilling my duties" and "fulfilling all the tasks that my job requires"), as well as in regards to their interpersonal skills (e.g., "establishing a good relationship with coworkers", "working well in a team") and also with skills related to creativity (e.g., "solving unexpected problems at the workplace..." or "adapting to changes that may occur in my duties"). The self-efficacy index in the SETE-ESR subscale was 3.42 (SD $=0.24 ; \mathrm{min}=1$ and $\max =5)$, suggesting that, when compared to the previous subscale, graduates had lower perceptions of self-efficacy. Graduates feel confident when they needed to self-regulate their emotions in the job-seeking process (e.g., "being persistent in my job-seeking", "not giving up looking for a job even if I have a lot of negative answers" and "continuing to think that I will get a job after a job refusal"). The self-efficacy index in the SETE-JSB subscale was 3.00 $(\mathrm{SD}=0.24 ; \min =1$ and $\max =5)$, the lowest of the three subscales $(\mathrm{M}<3.3)$. This suggests that graduates feel less confident about job-seeking behaviours, such as "getting guidance from employment support services at the university..." or "applying to an employment centre".

The linear regression model was significant for the SETE-AW subscale ( $p$-value $=$ $6.8 \times 10^{-4} ; \mathrm{R}^{2}=0.06$ ). In this model, age was significant and showed a positive effect on the self-efficacy index $(=0.011)$, that is, the older the age, the higher the self-efficacy in adapting to work. The regression model for the SETE-ESR scale was also significant $\left(p\right.$-value $\left.=4.5 \times 10^{-2} ; \mathrm{R}^{2}=0.043\right)$, with the response variable gender significant and with a positive effect $(=0.175)$, that is, male participants have higher self-efficacy in emotional regulation during the job-seeking process than females. The regression model developed for the SETE-JSB subscale was not found to be significant $\left(p\right.$-value $\left.=5.9 \times 10^{-1}\right)$. 
Table 2 considers the results of the Rpart Model and the relative importance of the independent variables in the explanation of data variation for each subscale.

Table 2. Independent variables of the Rpart model and their relative importance in the explanation of data variation for each subscale.

\begin{tabular}{cccc}
\hline Variables & \multicolumn{3}{c}{ Relative Importance (\%) } \\
\hline Age & SETE-AW & SETE-ESR & SETE-JSB \\
Gender & 31.52 & & 15.37 \\
Highest degree completed & 22.60 & 41.05 & \\
$\quad$ Scientific area & & 4.16 & \\
$\quad$ Grade point average & 25.28 & 20.34 & 53.03 \\
Higher Education Institution & 20.61 & & 29.22 \\
$\quad$ Internships & & & \\
Extracurricular activities & & & 2.38 \\
$\quad$ Work experience & & 22.77 & \\
Parents' level of education & & &
\end{tabular}

The Recursive Partitioning model (Rpart) developed for the SETE-AW subscale explained $63 \%$ of the data variance (i.e., deviance explained). Its simplification resulted in a tree with six leaves (Figure 1a; below). In this model, as in the regression model, the age of graduates was the variable best at explaining self-efficacy in adapting to work (relative importance $=31.5 \%$ ), followed by scientific area (relative importance $=25.3 \%$ ) The variables gender and grade also explained the data, with relative importance of $22.60 \%$ and $20.61 \%$, respectively (Table 2). Regarding the SETE-ESR subscale, the Rpart model explained $42 \%$ of the data variance, and its reduction resulted in a tree with six leaves (Figure 1b; below). As in the regression model, gender best explained self-efficacy in the emotional self-regulation during job-seeking (relative importance $=41.05 \%$ ). The variables parents' level of education and scientific area were also found as important (relative importance $=22.77 \%$ and $20.34 \%$, respectively). The variables HEI and highest degree had lesser relative importance $(<12 \%$ and $>4 \%)$ (Table 2$)$. The Rpart model developed for the SETE-JSB subscale explained $16 \%$ of the data variance, and its reduction resulted in a tree with six leaves (Figure 1c; below). The graduates' final average was the variable that best explained the self-efficacy of job-seeking behaviours (relative importance $=53 \%$ ), followed by internships (relative importance $=29 \%$ ). Age and parents' level of education were also important, although with lesser relative importance $(<20 \%)$ (Table 2$)$.

All independent variables included in the models were not found strongly correlated (Pearson' correlation $<0.5$; refer to supplementary information), thus allowing a straightforward discussion of their potential role in the models developed (Meloun et al. 2002).

The reduced Rpart model for the SETE-AW subscale (Figure 1a) showed that participants aged 37 years or older have higher self-efficacy in adapting to work $(M=4.4)$. From the youngest pool (under 24-year-olds), male participants showed a higher self-efficacy $(\mathrm{M}=4.3)$. Those aged between 24 and 36, who had completed Agricultural Sciences, Social Sciences, Health Sciences and Engineering and Technology, and with a grade point average above or equal to 13 out of 20 show higher self-efficacy $(M=4.2)$ when compared to participants of the same age group who had completed Exact Sciences, Natural Sciences and Humanities and with a grade point average of less than 13 values $(M=3.7)$. Female participants under 24 years old, similar to the latter group, showed less self-efficacy in adapting to work. 


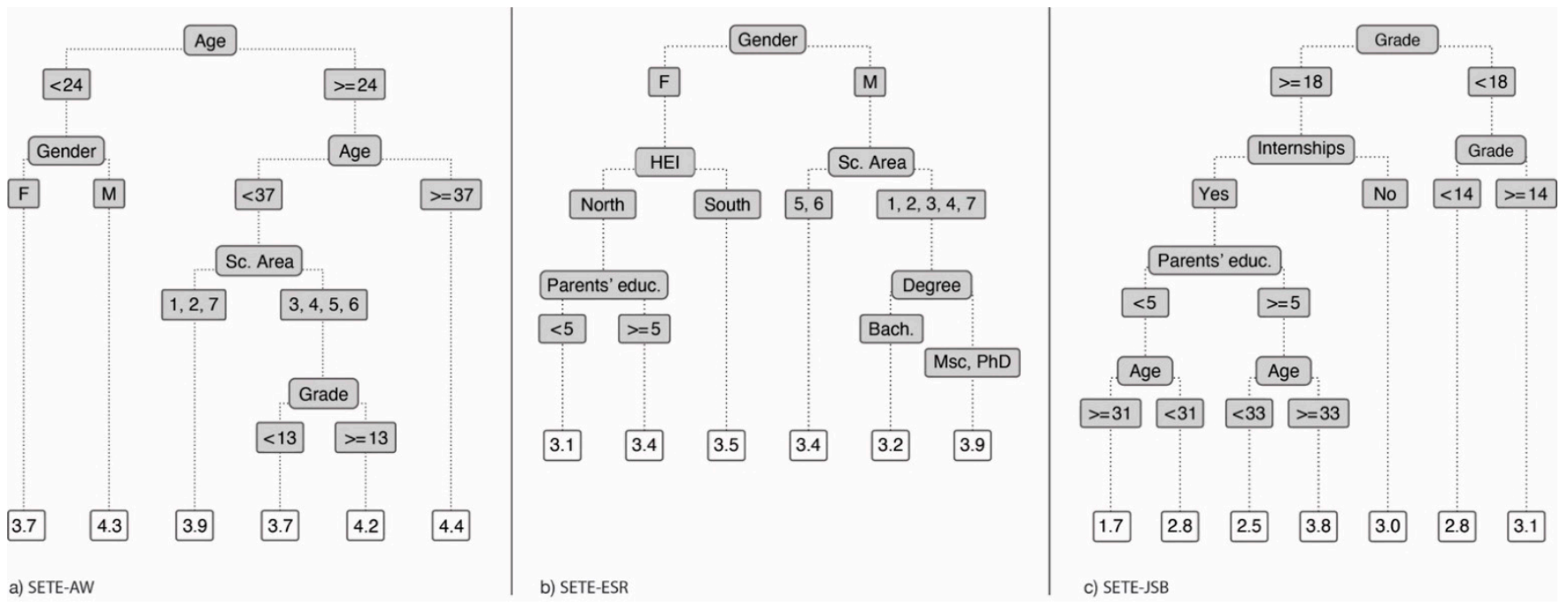

Figure 1. Reduced model of Recursive Partitioning for Classification by subscale: (a) Self-efficacy in the Transition to Employment-adapting to work-SETE-AW; (b) Self-efficacy in the Transition to Employment-emotional self-regulation in the job-seeking process-SETE-ESR; (c) Self-efficacy in the Transition to Employment-job-seeking behaviours-SETE-JSB. Sc. Area refers to the scientific areas: $1=$ Exact sciences; 2 = Natural Sciences; $3=$ Engineering and Technology; $4=$ Health Sciences; 5 = Agricultural Sciences; 6 = Social Sciences; $7=$ Humanities. Parent's educ. refers to the parent's level education: 1 = no qualifications; 2 = basic education key stage 1; 3 = basic education key stage 2; 4 = basic education key stage 3; $5=$ secondary education; and $6=$ tertiary education.

The model developed for the SETE-ESR subscale (Figure 1b) showed higher selfefficacy for male participants who had completed a master's or a PhD in Health Sciences, Exact Sciences, Natural Sciences, Engineering and Technology and Humanities $(\mathrm{M}=3.9)$. The female participants with a higher self-efficacy in emotional regulation were found to have completed their highest degree at the University in the South $(\mathrm{M}=3.5)$ or when at the University in the North but with at least one parent with schooling at a secondary or higher education level $(M=3.4)$. The participants with lower self-efficacy were males with a degree $(M=3.2)$ and females who completed the highest degree at the University of Minho with their parents' highest level of education at a level of basic education $(M=3.1)$.

Finally, the model for the SETE-JSB subscale tree (Figure 1c) showed that participants with higher self-efficacy in job-seeking behaviours had a grade point average higher or equal to 18 values out of 20 when undergoing internships. They had at least one parent at a secondary or tertiary education level and were aged 33 or over $(\mathrm{M}=3.8)$. However, within this group, graduates who are younger than 33 years old had much lower self-efficacy $(\mathrm{M}=2.5)$, as well as graduates who, despite having a grade point average higher or equal to 18 , did not undergo an internship $(\mathrm{M}=3)$. Those with a grade point average higher or equal to 18 who did undergo an internship but whose highest level of parents' education was a basic level and who were aged 31 or above had lower self-efficacy $(M=1.7)$ when compared to those under 31 years old $(\mathrm{M}=2.8)$. Participants with a grade point average between values of 14 and 17 presented higher self-efficacy $(M=3.1)$ when compared to those who had an average lower than 14 values $(\mathrm{M}=2.8)$.

\section{Discussion and Conclusions}

This study has allowed us to assess the role of a set of key variables in the transition to employment, showing that graduates have higher self-efficacy in their ability to adapt to work, compared to the emotional regulation in job-seeking and in the demonstration of job-seeking behaviours. These results are corroborated by recent studies carried out in the last decade with the scale of Self-Efficacy in the Transition to Employment-SETE (e.g., Barros 2018; Gamboa et al. 2018; Vieira and Theotonio 2018). By using a heterogeneous target group (e.g., covering a wide range of ages and all major degrees, from bachelor 
to $\mathrm{PhD}$ ) with a comprehensive set of unique personal variables (i.e., modelling variables not strongly correlated), the study has also allowed us to determine the drivers that best explain the different levels of self-efficacy in the three dimensions of the transition process. Graduates' age, gender, grade point average, scientific area of the highest degree completed, internships and parents' level of education proved to be particularly important.

The linear regression models and multivariate decision trees (i.e., Rpart) were consistent in the subscales related to adapting to work and emotional self-regulation in the job-seeking process, in which age and gender, respectively, were the variables with the highest explanatory power. The results revealed high performance, explaining more than $40 \%$ (Louviere et al. 2000) of the self-efficacy index of graduates with respect to adapting to work and emotional self-regulation in the job-seeking process. In the case of self-efficacy in job-seeking behaviours, the model explained less variance in the data, in line with the linear regression model, which did not detect any significant effect on the dependent variable. However, considering the flexibility of the Rpart algorithm and its capability of explaining variance (Gomes and Almeida 2017), it allowed us to draw some conclusions, namely, the potential effect of the grade point average of the highest degree completed and of internships on the self-efficacy of job-seeking behaviours.

In fact, the older the graduates (>36 years old), the higher the self-efficacy in adapting to work, which is confirmed in previous studies (e.g., Monteiro et al. 2016; Woodfield 2011). This can be explained by considering two of the four sources of self-efficacy beliefs (Bandura 1997), namely, mastery experiences and vicarious learning. In our study, with the average age of participants being approximately 30 years old, the higher self-efficacy can be explained by the fact that, on the one hand, older graduates can interpret new events considering past personal experiences. On the other hand, through vicarious learning obtained by observing role models (e.g., through previous experiences in a real work context that younger people have not had yet) and gathering information that contributes to judgments about their own abilities. The more opportunities in obtaining information from self-efficacy sources, the more confident they may be in their abilities, and the higher their tendency to be optimistic about the prospect of obtaining the results they seek (Lent et al. 1994). However, considering the mild correlation found between age and marital status, we cannot rule out the potential add-on effect of this variable excluded from our modelling approach. Studies considering both variables found no significant relationship between self-efficacy and marital status (e.g., Odanga et al. 2015; Seyedi-Andi et al. 2019), yet these were not focused on the specific process of graduates' transitioning to the labour market.

Male participants also displayed higher self-efficacy in emotional regulation in the job-seeking process. In addition, younger male graduates $(<24$ years) showed higher self-efficacy in adapting to work. This particular result does not seem to support other studies (e.g., Barros 2018; Gomes et al. 2019; Hernández-Fernaud et al. 2011), which found no significant differences in self-efficacy according to gender. Yet, gender, in our study, is related to the scientific area of the course in explaining self-efficacy in emotional selfregulation. More specifically, male participants who completed the highest degree in the areas of Health Sciences, Exact Sciences, Natural Sciences, Engineering and Technology and Humanities have higher self-efficacy in emotional regulation when compared with those in the areas of Social Sciences and Agricultural Sciences. This is in line with the Social Cognitive Career Theory (Lent et al. 1994), pointing out that the confidence of graduates in the transition to the labour market depends on personal and contextual characteristics.

The grade point average of the highest degree was positively associated with the self-efficacy of graduates in regard to job-seeking behaviours. This also explained, in part, the self-efficacy in adapting to work in the case of graduates aged between 24 and 36 who obtained an average grade higher or equal to 13, although the relative importance in this case was much lower when compared to that obtained in job-seeking behaviours. In this context, we can associate the impact of this variable with academic success, which is often operationalized through grades (Imose and Barber 2015). This suggests that the academic 
success of the graduates seems to contribute to an increase in confidence in the capacity of job-seeking behaviour and adaptation to work. However, academic success is not limited to grades (e.g., Cachia et al. 2018). There is widespread recognition that personal, social and academic factors influence success (e.g., Hardy and Bryson 2016; Tinto 2003). For example, the graduates with an average higher or equal to 18 may (or may not) show higher self-efficacy in seeking a job depending on the performance (or not) of an internship during their training. This confirms the contribution of internships in the perception that graduates have about the labour market and their preparation for the transition, which is documented in other studies (e.g., Silva et al. 2016; Tsai et al. 2017). In this sense, the variable internships can also fit into one of the sources of self-efficacy, namely, vicarious learning (Bandura 1997), promoting self-knowledge. Some authors (e.g., Samssudin and Barros 2010; Vieira and Theotonio 2018) have suggested that the higher the individual's awareness of their own abilities (and their limitations), the higher the confidence to face new challenges and manage career decisions.

In addition to internships, further learning in the work context (e.g., work placements, communities of practice, professional experiences, extracurricular activities) may further contribute to increasing the self-efficacy of graduates, especially in the case of younger graduates. These types of activities simulate real-life experiences and provide situations and tasks that graduates are likely to encounter in their first year of work. As some studies indicate (e.g., Gamboa et al. 2018; Gbadamosi et al. 2015; Monteiro 2018), students who had already had some sort of contact with the labour market showed higher self-efficacy in the transition to employment.

Finally, parents' level of education was also associated with self-efficacy in emotional self-regulation in the job-seeking process. In line with the importance of the family background in the construction of self-efficacy beliefs, parents' higher level of education is associated with students' higher self-confidence (Bussey and Bandura 1999; Teixeira 2007). The contribution of parents' level of education to the graduates' ability to self-regulate emotionally during their job-seeking can be explained considering another source of selfefficacy beliefs - verbal persuasion (Bandura 1997). Higher-educated parents can support their children during the transition process through better informed encouragement and advice (Mathatha and Ndhlovu 2018; Pajares 2002). This support can also come from the broader and more influential networks of personal and professional contacts that educated parents may have (Field 2016), which can serve as guidance in the process of job-seeking.

Overall, the results are in line with what the Social Cognitive Career Theory postulates (Lent et al. 1994). Graduates' confidence in the transition to the labour market stems from a set of relations within multiple factors-personal, social and contextual—and not from the impact of isolated factors. While variables such as age, gender, social class and parents' level of education, with an impact on the transition process, are not subject to transformation, there are certain actions taken by individuals (but also by HEIs) that can make a difference. For example, creating opportunities for interactions in contexts of professional practices during the academic path, promoting processes of social comparison and a reflective posture that promotes self-awareness and self-confidence, career counselling programs during HE attendance with the purpose of increasing students' self-knowledge and exploring the opportunities and challenges of the labour market.

\section{Limitation(s)}

We believe that this study contributes to a better understanding of the role of graduates' self-efficacy in the transition to the labour market, but there are limitations that we must consider. On the one hand, we must highlight the size of the sample, in the order of hundreds of graduates, as well as its heterogeneity, covering, for instance, a broad span of ages, degrees, scientific areas and two universities from two distinct socioeconomic contexts (the northern region, more represented by the business/industrial sector, and the southern region, more representative of services, specifically in the tourism sector). However, the sample might not be completely representative. Therefore, we suggest 
extending the sample to HEIs from other regions of the country in order to allow for a comparative analysis between different contexts. On the other hand, the models processed did not explain the total variance of the data, so it would be important to consider the contribution of other variables in future research. For instance, the job seeking strategies included in the three scales used in our study could be expanded beyond those available.

Supplementary Materials: The following are available online at https:/ / www.mdpi.com/article / $10.3390 /$ socsci10110406/s1.

Author Contributions: Conceptualization, L.P., S.T.V. and L.S.A.; data curation, L.P.; formal analysis, L.P.; funding acquisition, L.P., S.T.V. and L.S.A.; investigation, L.P.; methodology, L.P., S.T.V. and L.S.A.; project administration, L.P.; resources, L.P. and S.T.V.; software, L.P.; supervision, S.T.V. and L.S.A.; writing —original draft, L.P. and S.T.V.; writing—review and editing, S.T.V. and L.S.A. All authors have read and agreed to the published version of the manuscript.

Funding: This research was funded by National Funds through FCT-Foundation for Science and Technology under the grant number SFRH/BD/132068/2017; Project UIDB/05739/2020; and Projects UIDB/01661/2020 and UIDP/01661/2020.

Institutional Review Board Statement: The study was conducted according to the guidelines of the Declaration of Helsinki and approved by the Ethics Committee for Research in Social and Human Sciences of University of Minho (protocol code CE.CSH 096/2018; approved on 27 August 2019).

Informed Consent Statement: Informed consent was obtained from all subjects involved in the study.

Data Availability Statement: The data that support the findings of this study are openly available in Supplementary Material.

Conflicts of Interest: The authors declare no conflict of interest.

\section{References}

Almeida, Leandro S., Claisy Maria Marinho-Araújo, Alberto Amaral, and Diana Dias. 2012. Democratização do Acesso e do Sucesso no Ensino Superior: Uma Reflexão a partir das Realidades de Portugal e do Brasil. Avaliação 17: 899-920. [CrossRef]

Almeida, António, Helena Quintas, and Teresa Gonçalves. 2016. Estudantes Não-Tradicionais no Ensino Superior: Barreiras à Aprendizagem e na Inserção Profissional. Laplage em Revista (Sorocaba) 2: 97-111. [CrossRef]

Alves, Mariana G., and Vesa Korhonen. 2016. Transitions and Trajectories from Higher Education to Work and back-A Comparison between Finnish and Portuguese Graduates. European Educational Research Journal 15: 676-95. [CrossRef]

Bandura, Albert. 1982. Self-efficacy Mechanism in Human Agency. American Psychologist 37: 122-47. [CrossRef]

Bandura, Albert. 1997. Self-Efficacy: The Exercise of Control. New York: W. H. Freeman and Company.

Barros, Alexandra. 2018. Crenças de Carreira na Transição do Ensino Superior para o Trabalho. Revista. Brasileira de Orientação Profissional 19: 133-42. [CrossRef]

Bussey, Kay, and Albert Bandura. 1999. Social Cognitive Theory of Gender Development and Differentiation. Psychological Review 106: 676-713. [CrossRef] [PubMed]

Cachia, Moira, Siobhan Lynam, and Rosemary Stock. 2018. Academic Success: Is it Just About the Grades? Higher Education Pedagogies 3: 434-39. [CrossRef]

Castro, Rui V., and Leandro S. Almeida. 2016. Ser estudante no ensino superior: Observatório dos percursos académicos dos estudantes da UMinho. In Ser Estudante no Ensino Superior: O Caso dos Estudantes do $1^{\circ}$ ano. Edited by Leandro S. Almeida and Rui Vieira de Castro. Braga: Centro de Investigação em Educação, Instituto de Educação, Universidade do Minho, pp. 1-14.

Daikeler, Jessica, Michael Bosnjak, and Katja Lozar Manfreda. 2019. An Updated and Extended Meta-Analysis Comparing Response Rates. Journal of Survey Statistics and Methodology 0: 1-27.

Directorate-General of Education and Science Statistics-DGESS. 2020. Diplomados do Ensino Superior. Available online: https: //www.dgeec.mec.pt/np4/EstatDiplomados / (accessed on 1 July 2021).

Field, John. 2016. Social Capital, 3rd ed. London: Routledge.

Gamboa, Vitor, Olímpio Paixão, João Gomes, Alex Silva, and Patrícia Bento. 2018. Empregabilidade percebida, adaptabilidade de carreira e autoeficácia na transição para o trabalho: Diferenças entre estudantes e trabalhadores-estudantes. Educação, Sociedade E Culturas 52: 65-82. [CrossRef]

Gbadamosi, Gbolahan, Carl Evans, Mark Richardson, and Mark Ridolfo. 2015. Employability and students' part-time work in the UK: Does self-efficacy and career aspiration matter? British Educational Research Journal 41: 1086-1107. [CrossRef]

Gomes, Cristiano M., and Leandro S. Almeida. 2017. Advocating the Broad use of the Decision Tree Method in Education. Practical Assessment, Research \& Evaluation 22: 1-10. 
Gomes, João, Vitor Gamboa, and Olímpio Paixão. 2019. Intenções de Procura de Emprego no Ensino Superior: Empregabilidade Percebida e Autoeficácia. Revista Brasileira de Orientação Profissional 20: 85-94.

Grosemans, Ilke, and Eva Kyndt. 2017. Transitions from Higher Education to the Labour Market: State of the Art. In Higher Education Transitions: Theory and Research. Edited by Eva Kyndt, Vincent Donche, Keith Trigwell and Sari Lindblom-Ylänne. London and New York: Routledge, pp. 209-18.

Hardy, Christine, and Colin Bryson. 2016. The Salience of Social Relationships and Networks in Enabling Student Engagement and Success. Student Engagement in Higher Education Journal 1: 1-20.

Hernández-Fernaud, Estefanía, Yeray Ramos-Sapena, Fátima Negrín, Carmen Inés Ruiz-de la Rosa, and Bernardo Hernández. 2011. Empleabilidad Percibida y Autoeficacia para la Búsqueda de Empleo en Universitarios. Revista de Psicología del Trabajo y de las Organizaciones 27: 131-42.

Holmes, Leonard. 2013. Competing Perspectives on Graduate Employability: Possession, Position or Process? Studies in Higher Education 38: 538-54. [CrossRef]

Imose, Ruth, and Larissa K. Barber. 2015. Using Undergraduate Grade Point Average as a Selection Tool: A Synthesis of the Literature. The Psychologist-Manager Journal 18: 1-11. [CrossRef]

Lent, Robert W., Steven D. Brown, and Gail Hackett. 1994. Toward a Unifying Social Cognitive Theory of Career and Academic Interest, Choice, and Performance. Journal of Vocational Behavior 45: 79-122. [CrossRef]

Lent, Robert W., Gail Hackett, and Steven. D. Brown. 1999. A social cognitive view of school-to-work transition. The Career Development Quarterly 47: 297-311. [CrossRef]

Lopez-Zafra, Juan M., Ricardo Queralt-Sanchez, and Sonia Paz-Cobo. 2019. Admission Tools and Academic Performance: Evidence from a First Course in a Bachelor's Degree in Business Administration. In HEAD'19, Paper Presented at 5th International Conference on Higher Education Advances, Valencia, Spain, June 25-28. Valencia: Editorial Universitat Politècnica de València, pp. 573-81.

Louviere, Jordan, David Hensher, and Joffre Swait. 2000. Stated Choice Methods: Analysis and Applications. New York: Cambridge University Press.

Marinho-Araujo, Claisy, and Leandro S. Almeida. 2016. Approach to competences, human development and higher education. Psicologia: Teoria e Pesquisa 32: 1-9.

Mathatha, Viola, and Daniel Ndhlovu. 2018. Influence of Parental Education on Career Development of Youths with Intellectual Disabilities in Selected Skills Training Institutions in Zambia. International Journal of Humanities Social Sciences and Education 5: $142-50$.

Meloun, Milan, Jiri Militky, Hill Martin, and Richard G. Brereton. 2002. Crucial problems in regression modelling and their solutions. Analyst 127: 433-50. [CrossRef] [PubMed]

Monteiro, Sílvia. 2018. Estudar e Trabalhar, Barreira ou Oportunidade: Estudo Comparativo entre Estudantes Trabalhadores e Estudantes não Trabalhadores. In Estudantes Não-Tradicionais no Ensino Superior. Edited by António Fragoso and Sandra T. Valadas. Coimbra: CINEP, pp. 251-73.

Monteiro, Sílvia, Leandro S. Almeida, and Adela García-Aracil. 2016. Graduates' Perceptions of Competencies and Preparation for Labour Market Tansition. Higher Education, Skills and Work-Based Learning 6: 208-20. [CrossRef]

Nachev, Anatoli. 2017. Measuring Factors of Employment by Classification Tree Models. International Journal of Engineering and Advanced Technology 7: 2249-8958.

Nicholson, Nigel. 1991. The transition cycle: Causes, outcomes, processes and forms. In On the Move: The Psychology of Change and Transition. Edited by Shirley Fisher and Cary L. Cooper. New York: Wiley, pp. 83-108.

Nunes, Maiana F. 2008. Funcionamento e Desenvolvimento das Crenças de Auto-eficácia: Uma Revisão. Revista Brasileira de Orientação Profissional 9: 29-42.

Odanga, Sylvester J. O., Peter J. O. Aloka, and Pamela Raburu. 2015. Influence of Marital Status on Teachers' Self-Efficacy in Secondary Schools of Kisumu County, Kenya. Academic Journal of Interdisciplinary Studies 4: 115-24. [CrossRef]

Pajares, Frank. 2002. Gender and Perceived Self-efficacy in Self-regulated Learning. Theory Into Practice 41: 116-25. [CrossRef]

Pires, Lília A. 2016. Estudantes com necessidades educativas especiais no ensino superior: Respostas Institucionais. In Ser Estudante no Ensino Superior: O Caso dos Estudantes do $1^{\circ}$ ano. Edited by Leandro S. Almeida and Rui V. Castro. Braga: Centro de Investigação em Educação, Instituto de Educação, Universidade do Minho, pp. 64-80.

Pordata. 2021. Alunos Matriculados no Ensino Superior: Total e Por Área de Educaç ão e Formação. Available online: https://www. pordata.pt/Portugal/Alunos+matriculados+no+ensino+superior+total+e+por+área+de+educaç ao+e+formaç ao-1026 (accessed on 1 July 2021).

R Development Core Team. 2020. R: A Language and Environment for Statistical Computing. Vienna: R Foundation for Statistical Computing.

Samssudin, Sara, and Alexandra Barros. 2010. Relação entre as Crenças de Auto-eficácia e o Apoio Social na Transição para o Trabalho em Estudantes Finalistas do Ensino Superior. In Actas do VII Simpósio Nacional de Investigação em Psicologia. Braga: Universidade do Minho, pp. 3834-43.

Schlossberg, Nancy. 2011. The challenge of chance: The transition model and its applications. Journal of Employment Counseling 48: 159-63. [CrossRef]

Schofer, Evan, and John W. Meyer. 2005. The world-wide expansion of Higher Education in the twentieth century. American Sociological Review 70: 898-920. [CrossRef] 
Schutt, Russell K. 2018. Investigating the Social World: The Process and Practice of Research, 9th ed. Boston: Sage.

Seyedi-Andi, Seyed Jalil, Fatemeh Bakouei, Hajar Adib Rad, Soraya Khafri, and Asgari Salavati. 2019. The relationship between self-efficacy and some demographic and socioeconomic variables among Iranian Medical Sciences students. Advances in Medical Education and Practice 10: 645-51. [CrossRef]

Silva, Patrícia, Betina Lopes, Marco Costa, Dina Seabra, Ana Melo, Elisabeth Brito, and Gonçalo Paiva Dias. 2016. Stairway to employment? Internships in higher education. Higher Education 72: 703-21. [CrossRef]

Strobl, Caroline, James Malley, and Gerhard Tutz. 2009. An Introduction to Recursive Partitioning: Rationale, Application, and Characteristics of Classification and Regression Trees, Bagging, and Random Forests. Psychological Methods 14: 323-48. [CrossRef]

Teixeira, Maria O. 2007. As crenças de Eficácia Académica na Formação dos Interesses e das Escolhas Vocacionais. Psychologica 44: $11-23$.

Therneau, Terry, Atkinson Beth, and Ripley Brian. 2013. Rpart: Recursive Partitioning. R Package Version 4.1-3. Available online: http:/ / dirk.eddelbuettel.com/cranberries/2013/12/10/ (accessed on 1 July 2021).

Tinto, Vincent. 2003. Learning Better Together: The Impact of Learning Communities on Student Success. Higher Education Monograph Series 1: 1-8.

Tsai, Chen-Tsang, Hsuan Hsu, and Chun-Chin Yang. 2017. Career Decision Self-efficacy Plays a Crucial Role in Hospitality Undergraduates Internship Efficacy and Career Preparation. Journal of Hospitality, Leisure, Sport E Tourism Education 21: 61-68.

Valadas, Sandra T., Liliana Paulos, and Scott Revers. 2018. A transição de estudantes não-tradicionais para o mercado de trabalho: Género, idade, experiência e insegurança. In Estudantes Não-Tradicionais no Ensino Superior. Edited by António Fragoso and Sandra T. Valadas. Coimbra: CINEP, pp. 275-96.

Vieira, Diana A. 2012. Transição do Ensino Superior Para o Trabalho: O Poder da Autoeficácia e Dos Objetivos Profissionais. Porto: Vida Económica/Fundação Politécnico do Porto.

Vieira, Diana A., and Joaquim L. Coimbra. 2005. University-to-work Transition: The Development of a Self-efficacy Scale. In Communication Presented in AIOSP International Conference 2005-Careers in Context: New Challenges and Tasks for Guidance and Counselling. Lisboa: Universidade de Lisboa, p. 106.

Vieira, Diana A., and Maria Theotonio. 2018. Autoeficácia e Sucesso na Transição do Ensino Superior. Revista Brasileira de Orientação Profissional 19: 31-39.

Woodfield, Ruth. 2011. Age and First Destination Employment from UK Universities: Are Mature Students Disadvantaged? Studies in Higher Education 36: 409-25. [CrossRef] 